Pemanfaatan Jurnal Online Perpustakaan BPTP Yogyakarta Dwi Titaningsih, Suharno

Kerja Sama antara SDM Perpustakaan untuk Menuju Layanan Prima dan Unggul Endang Fatmawati

Revitalisasi Peran Perpustakaan Umum bagi Masyarakat Noorika Retno Widuri

Optimalisasi Layanan Penelusuran Sumber-sumber Informasi untuk Mendukung Penulisan Karya Ilmiah Dosen dan Mahasiswa di Perguruan Tinggi Dian Hapsari

Memperkuat Peran Pustakawan dalam Mewujudkan Layanan Perpustakaan Perguruan Tinggi yang Prima dan Unggul Bambang Hermanto

Aktivitas Mahasiswa dalam Membaca Skripsi di Perpustakaan Masriyatun

Budaya Peduli dan Budaya Mutu Melayani di Perpustakaan SMP Negeri 13 Surakarta Menuju Sekolah Menyenangkan Ria Widyawati

Redesain Website UPT Perpustakaan Universitas Sebelas Maret sebagai Media Pendidikan Pengguna bagi Pemustaka Tri Hardian Satiawardana

Peran Perpustakaan dalam Membangun Citra Perpustakaan di Era Teknologi Informasi Sri Anawati

Komunitas Pustakawan Menulis (upaya menyebarluaskan dan melestarikan pengetahuan) Tri Hardiningtyas 


\section{Jurnal}

\section{Pustaka Ilmiah}

\section{Jurnal Ilmiah UPT Perpustakaan UNS}

Jurnal Pustaka Ilmiah (JPI) sebagai media kreasi para pustakawan, guru, dosen, dan praktisi dalam pengembangan profesi secara berkelanjutan. Berbagai ide dan gagasan kreatif menjadi bahan kajian yang diimplementasikan dalam berbagai model pengembangan bahan pustaka, baik cetak maupun online. Kreativitas menjadi akar pengembangan ilmu pengetahuan sepanjang hayat dengan berbagai model pengembangan budaya literasi di perpustakaan. Keindahan dan kecermatan dalam sebuah tulisan ilmiah dan nonilmiah akan dapat direalisasikan secara nyata oleh sumber daya manusia untuk menghasilkan SDM yang unggul dan kreatif dengan membaca dan menulis untuk menyinari dunia. Budaya literasi menjadi upaya untuk pengembangan dan pemberdayaan perpustakaan sebagai pusat sumber belajar untuk mendukung tri dharma perguruan tinggi.

\section{SUSUNAN REDAKSI}

Penanggung Jawab

Ketua Redaksi

Wakil Redaksi

Sekretaris

Penyunting Ahli

Penyunting

Bendahara

Sirkulasi
: Dr. Muhammad Rohmadi, M.Hum.

: Dra. Tri Hardiningtyas, M.Si.

: Haryanto, M.IP.

: Bambang Hermanto, S.Pd., M.IP., Henny Perwitosari, A.Md.

: 1. Dr. Muhammad Rohmadi, M.Hum. (Universitas Sebelas Maret);

2. Drs. Widodo, M.Soc.Sc. (Universitas Sebelas Maret);

3. Drs. Harmawan, M.Lib. (Universitas Sebelas Maret).

: Daryono, S.Sos., M.IP.; RiahWiratningsih, S.S., M.Si., Dinar Puspita Dewi, S.Sos., M.IP.; Sri Utari, S.E.

: Nurul H., A. Md.; Novi Tri Astuti, A.Md.

: Aji Hartono, A. Md.; Agus Sriyono, A.Md.; Aris Suprihadi, S.IP.

UPT PERPUSTAKAAN UNS

REDAKSI JURNAL PUSTAKA ILMIAH

Alamat: Jl. Ir. Sutami 36A Kentingan, Surakarta 57126

Telp./Fax.: (0271) 654311; email: jurnal.pustaka.ilmiah@gmail.com 


\section{Pengantar Redaksi}

\section{Salam Pustaka.}

Dengan mengucap rasa syukur kepada Allah SWT. segenap Tim Redaksi Jurnal Pustaka Ilmiah (JPI) mengucapkan banyak terima kasih kepada para penulis yang telah berkontribusi untuk penerbitan JPI volume 2 edisi Juni 2016. Penerbitan volume 2 kali ini JPI mengetengahkan tema: Pengembangan Perpustakaan menuju Layanan Prima dan Unggul. Kehadiran JPI diharapkan dapat dijadikan sebagai media penulisan bagi para pustakawan, dosen, tenaga kependidikan, guru, dan praktisi untuk menuangkan ide dan gagasan kreatifnya secara tertulis.

Dalam penerbitan JPI volume 2 bulan Juni 2016 ini disajikan sepuluh tulisan antara lain: (1) Pemanfaatan Jurnal Online Perpustakaan BPTP Yogyakarta (Dwi Titaningsih dan Suharno), (2) Kerja Sama Antara Sumber Daya Manusia Perpustakaan untuk Menuju Layanan Prima dan Unggul (Endang Fatmawati), (3) Revitalisasi Peran Perpustakaan Umum Bagi Masyarakat (Noorika Retno Widuri), (4) Optimalisasi Layanan Penelusuran Sumber-Sumber Informasi untuk Mendukung Penulisan Karya Ilmiah Dosen dan Mahasiswa di Perguruan Tinggi (Dian Hapsari), (5) Memperkuat Peran Pustakawan dalam Mewujudkan Layanan Perpustakaan Perguruan Tinggi yang Prima dan Unggul (Bambang Hemanto), (6) Aktivitas Mahasiswa dalam Membaca Skripsi di Perpustakaan FISIP-UNS (Masriyatun), (7) Budaya Peduli dan Budaya Mutu Melayani di Perpustakaan SMP Negeri 13 Surakarta Menuju Sekolah Menyenangkan (Ria Widyawati), (8) Redesain Website UPT Perpustakaan Universitas Sebelas Maret Surakarta sebagai Media Pendidikan Pengguna Bagi Pemustaka (Tri Hardian Satiawardana), (9) Peran Perpustakaan dalam Membangun Citra Perpustakaan di Era Teknologi Informasi (Sri Anawati), (10) Komunitas Pustakawan Menulis : upaya menyebarluaskan dan melestarikan pengetahuan (Tri Hardiningtyas).

Akhirnya, redaksi JPI mengucapkan banyak terima kasih kepada Kepala UPT Perpustakaan UNS yang telah memberikan dukungan dan memfasilitasi untuk penerbitan JPI. Selain itu, ucapan terima kasih juga disampaikan kepada para penulis, tim redaksi, dan Yuma Pressindo, yang telah mempersiapkan dari awal sampai terbitnya JPI. Selamat membaca.

Surakarta, Juni 2016

Ketua Redaksi 


\section{Sambutan}

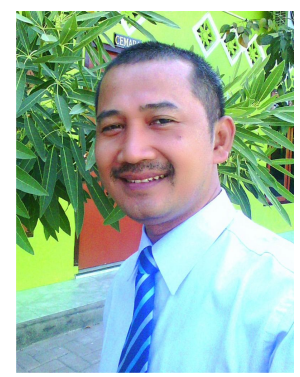

Dr. Muhammad Rohmadi, M.Hum.

\section{Kepala UPT Perpustakaan UNS}

Selamat dan sukses atas diterbitkannya kembali Jurnal Pustaka Ilmiah (JPI). Jurnal ini sebagai media kreativitas dan pengembangan softs skills para pustakawan, guru, dosen, dan praktisi untuk menuangkan ide dan gagasan demi layanan perpustakaan yang prima dan unggul. Berbagai isu terkait dengan pengembangan perpustakaan, pelayanan perpustakaan sebagai pusat sumber belajar, pendidikan, penelitian, pelestarian, dan budaya literasi akan menjadi topik-topik yang disajikan dalam jurnal ilmiah ini.

Diterbitkannya JPI sebagai bukti kepedulian UPT Perpustakaan Universitas Sebelas Maret Surakarta (UNS) dalam rangka turut berpartisipasi mengembangkan dan membudayakan literasi untuk para pustakawan dan civitas akademika di UNS maupun luar UNS. Berbagai model pengembangan softs skills menjadi alternatif untuk membekali dan memperkuat jaringan kerja sama penulisan antar kelembagaan. Dengan demikian, kerja sama antar pustakawan dan pemustaka dapat diwujudkan dengan berbagai model dalam bidang literasi.

Penerbitan JPI merupakan sarana untuk memotivasi semua pustakawan agar berkarya di bidang penulisan, baik ilmiah maupun nonilmiah. Para pustakawan harus menjadi pionir dalam bidang penulisan. Hal ini sebagai bentuk kepedulian dan keteladaan para pustakawan yang memproses, menyajikan, dan menikmati bahan-bahan pustaka cetak dan noncetak di perpustakaan. Ketersedian bahan pustaka akan menjadi bahan paling nyata untuk dikembangkan dalam berbagai model perwujudan teknik penulisan. Hal terpenting yang harus dimiliki oleh para pustakawan adalah semangat untuk berbagi pengetahuan melalui tulisan.

Kepedulian setiap sumber daya manusia kepada kelembagaan dapat dituangkan dalam berbagai model pengabdian, salah satunya adalah melalui tulisan. Berbagai ide dan gagasan dapat direalisasikan dengan berbagai model bentuk artikel jurnal, buku, modul, monograf, dan lain sebagainya. Para civitas akademika, guru, praktisi harus memiliki keterampilan menulis sebagai bentuk perwujudan pengembangan diri secara berkelanjutan. Berbagai tulisan dan referensi sudah disajikan tetapi masih sangat minim untuk diimplementasikan dalam kehidupan. Banyak orang pandai dalam berbicara tetapi masih sedikit yang menuangkan ide dan gagasannya dalam bentuk tulisan.

Akhirnya, keluarga besar UPT Perpustakaan UNS mengucapkan banyak terima kasih kepada Rektor, Wakil Rektor, pengelola JPI, penulis, dan semua pihak yang telah mendukung penerbitan JPI. Semoga dengan diterbitkannya JPI ini dapat menjadi media untuk menulis para pustakawan, dosen, guru, dan praktisi dalam bidang iptek dan seni. Ucapan terima kasih juga diucapkan kepada percetakan Yuma Pressindo yang telah membantu mempersiapkan dari awal sampai terbitnya JPI ini. Akhirnya, semoga JPI dapat memberikan nilai kemaslahatan untuk umat. 


\section{DAFTAR ISI}

\section{JURNAL PUSTAKA ILMIAH EDISI KEDUA: VOLUME 1 NOMOR 2/ JUNI 2016}

\section{Tema: Pengembangan Perpustakaan Menuju Layanan Prima dan Unggul}

Pemanfaatan Jurnal Online Perpustakaan BPTP Yogyakarta

Dwi Titaningsih, Suharno

Kerja Sama antara SDM Perpustakaan untuk Menuju Layanan Prima dan Unggul

Endang Fatmawati

Revitalisasi Peran Perpustakaan Umum bagi Masyarakat.

Noorika Retno Widuri

Optimalisasi Layanan Penelusuran Sumber-sumber Informasi untuk Mendukung Penulisan Karya Ilmiah Dosen dan Mahasiswa di Perguruan Tinggi..

Dian Hapsari

Memperkuat Peran Pustakawan dalam Mewujudkan Layanan Perpustakaan Perguruan Tinggi yang Prima dan Unggul.

Bambang Hermanto

Aktivitas Mahasiswa dalam Membaca Skripsi di Perpustakaan

Masriyatun

Budaya Peduli dan Budaya Mutu Melayani di Perpustakaan SMP Negeri 13 SurakartaMenuju SekolahMenyenangkan.

Ria Widyawati

Redesain Website UPT Perpustakaan Universitas Sebelas Maret sebagai Media Pendidikan Pengguna bagi Pemustaka.

Tri Hardian Satiawardana

Peran Perpustakaan dalam Membangun Citra Perpustakaan di Era Teknologi Informasi

Sri Anawati

Komunitas Pustakawan Menulis (upaya menyebarluaskan dan melestarikan pengetahuan)

Tri Hardiningtyas 


\title{
MEMPERKUAT PERAN PUSTAKAWAN DALAM MEWUJUDKAN LAYANAN PERPUSTAKAAN PERGURUAN TINGGI YANG PRIMA DAN UNGGUL
}

\author{
Bambang Hermanto \\ Pustakawan Universitas Sebelas Maret Surakarta \\ Email: bambangh@uns.ac.id
}

\begin{abstract}
The establishment of the college library aims to support the achievement of the vision of the mission of higher education in implementing the Tri Dharma College, namely education, research, and community service. The role of the library in this regard include satisfying the information needs of academicians, providing library materials, provide study rooms, providing lending services and providing information services. Library is the heart of the college. Library as a source of information must be managed properly and professionally. To realize the excellent service and superior, then the college library services should beroreintasi on satisfaction and customer focus. For strengthening the role of the librarian, then the librarian skills and knowledge on the basics of the service must be improved through education, training, workshops, workshops and seminars, in order to achieve service excellence and superior library. There is also the strategy of librarians in strengthening its role in the realization of library services college superior and primed to consider several things, among others: (1) improving the competence of librarianship, (2) maintain the appearance, (3) confident, smiling, being friendly, and friends, (4) listen to each conversation and received no complaints with either, (5) speak the language properly and clearly, (6) enthusiastic in providing services and show the ability, (7) if it can not resolve the existing problems, can work together with other librarians.
\end{abstract}

Keywords: the role of librarians, college libraries, excellent service and superior

\begin{abstract}
ABSTRAK
Berdirinya perpustakaan perguruan tinggi bertujuan untuk mendukung tercapainya visi misi perguruan tinggi dalam melaksanakan Tri Dharma Perguruan Tinggi, yaitu pendidikan, penelitian, dan pengabdian pada masyarakat. Peran perpustakaan dalam hal ini meliputi memenuhi kebutuhan informasi bagi sivitas akademika, menyediakan bahan pustaka, menyediakan ruangan belajar, menyediakan jasa peminjaman dan menyediakan jasa informasi. Perpustakaan merupakan jantungnya perguruan tinggi. Perpustakaan sebagai sumber informasi harus dikelola dengan baik dan profesional. Untuk mewujudkan layanan yang prima dan unggul, maka layanan perpustakaan perguruan tinggi harus beroreintasi pada kepuasan dan fokus kepada pelanggan. Untuk penguatan peran pustakawan, maka kemampuan dan pengetahuan pustakawan mengenai dasar-dasar layanan harus ditingkatkan melalui pendidikan, pelatihan, lokakarya, workshop, dan seminar, dalam rangka tercapainya layanan perpustakaan yang prima dan unggul. Ada pun startegi pustakawan dalam memperkuat perannya dalam mewujudkan layanan perpustakaan perguruan tinggi yang unggul dan prima dengan memperhatikan beberapa hal, antara lain: (1) peningkatan kompetensi kepustakawanan, (2) menjaga penampilan, (3) percaya diri, penuh senyum, bersikap ramah, dan bersahabat, (4) mendengarkan setiap pembicaraan dan menerima keluhan
\end{abstract}


dengan baik, (5) berbicara dengan bahasa yang benar dan jelas, (6) antusias dalam memberikan layanan dan tunjukan kemampuan, (7) apabila tidak bisa mengatasi permasalahan yang ada, dapat bekerja sama dengan pustakawan lain.

Kata kunci: peran pustakawan, perpustakaan perguruan tinggi, layanan prima dan unggul

\section{PENDAHULUAN}

Perpustakaan perguruan tinggi didirikan untuk mendukung tercapainya visi misi perguruan tinggi dalam melaksanakan Tri Dharma Perguruan Tinggi. Perpustakaan merupakan jantungnya perguruan tinggi. Perpustakaan harus dapat menggerakkan atmosfer pembelajaran dengan menyediakan koleksi, jenis layanan, sarana prasarana, dan ruang perpustakaan yang dapat mendukung visi misi perguruan tinggi induknya.

Perkembangan teknologi akan mempengaruhi perubahan perilaku pemustaka dalam melakukan temu kembali informasi. Perpustakaan dalam memberikan pelayanan kepada pemustaka diharapkan dapat memberikan layanan yang prima dan unggul. Menurut Undang-Undang Perpustakaan nomor 47 tahun 2007 tentang Layanan Perpustakaan, layanan perpustakaan harus dilakukan secara prima dan berorientasi pada kepentingan pemustaka.

Pustakawan merupakan unsur penting dalam terselenggaranya kegiatan perpustakaan. Pustakawanlah yang menggerakkan sendisendi layanan perpustakaan. Pustakawan dapat dikatakan sebagai ujung tombaknya perpustakaan. Baik buruknya layanan perpustakaan tergantung dari kualitas layanan yang diberikan pustakawan kepada pemustaka. Pustakawan sebagai pejabat fungsional dituntut untuk senantiasa memberikan layanan yang prima kepada pemustaka.

Pustakawan dalam memberikan layanan perpustakaaan akan berhubungan langsung dengan pemustaka yang mempunyai karakter yang berbeda-beda. Mayoritas pemustaka mendambakan layanan perpustakaan yang prima dan unggul. Banyak tidaknya pemustaka yang memanfaatkan perpustakaan tergantung dari kualitas layanan yang telah diberikan. Kualitas layanan yang baik tidak lepas dari peran pustakawan. Hal ini dipertegas Ismawan (2014: 1), bahwa layanan perpustakaan yang prima tidak lepas dari kemampuan pustakawan dalam melaksanakan layanan secara optimal. Pustakawan dapat menggabungkan konsep kemampuan, penampilan, sikap, tindakan, perhatian, dan tanggung jawab dalam memberikan layanan perpustakaan.

Berdasarkan latar belakang masalah di atas, penulismembahas persoalanutamayang menjadi topik pada tulisan ini yaitu bagaimana strategi pustakawan dalam menguatkan perannya dalam mewujudkan layanan perpustakaan perguruan tinggi yang prima dan unggul.

\section{PEMBAHASAN}

\section{Konsep Layanan Prima dan Unggul}

Dalam mewujudkan layanan perpustakaan yang prima dan unggul, bukan pekerjaan yang mudah. Banyak faktor yang harus dipertimbangkan secara cermat untuk memperoleh kualitas layanan yang berdampak pada budaya organisasi secara menyeluruh. Untuk mewujudkan layanan perpustakaan yang prima dan unggul, perpustakaan dapat memperhatikan beberapa hal.

Pertama, reliabilitas. Perpustakaan dapat memberikan layanan secara benar, dapat memenuhi janji secara akurat dan andal. Perpustakaan dalam memberikan layanan sesuai dengan jam buka, ketentuan jumlah peminjaman buku, hak-hak anggota terpenuhi, 
serta melakukan penagihan denda dan penagihan buku yang terlambat secara akurat.

Kedua, responsivitas. Responsivitas atau daya tanggap, meliputi kesediaan dan kesiapan pustakawan untuk membantu dan melayani pemustaka dengan segera. Pustakawan dapat memberikan layanan yang ketepatan dan akurat. Pustakawan akan membantu pemustaka yang mengalami kesulitan dalam melakukan temu kembali informasi. Pemustaka tidak harus menunggu lama untuk menerima layanan perpustakaan.

Ketiga, kompetensi pustakawan. Pustakawan mempunyai kompetensi dalam penguasaan keterampilan dan pengetahuan yang dibutuhkan untuk memberikan layanan sesuai dengan kebutuhan pemustaka. Kompetensi ini harus dimiliki oleh semua elemen yang ada di perpustakaan, termasuk tenaga tata usaha, tenaga magang akademik, magang profesi, satpam, dan penjaga sepeda.

Keempat, akses. Akses ini meliputi kemudahan untuk dihubungi dan kemudahan kontak ke perpustakaan. Perpustakaan dapat menyediakan kontak di website, kotak saran, e-mail, telepon, Facebook, What's App, Line, dan surat. Pemustaka dapat menghubungi dan kontak langsung ke Perpustakaan apabila membutuhkan informasi tentang perpustakaan.

Kelima, kesopanan. Kesopanan meliputi sikap pustakawan yang santun, ramah, respek dan atensi. Kesopanan ini dapat ditunjukkan saat melakukan layanan perpustakaan, menerima telepon, dan menerima tamu, baik dari internal maupun eksternal instansi. Pemustaka yang datang ke perpustakaan disambut dengan $5 \mathrm{~S}$, yaitu senyum, salam, sapa, sopan dan santun.

Keenam, komunikasi. Pustakawan dalam menyampaikan informasi kepada pemustaka menggunakan bahasa yang mudah dipahami. Perpustakaan menyediakan kotak saran dan menerima keluhan dari pemustaka sebagai bahan pertimbangan untuk perbaikan pelayanan perpustakaan yang berkelanjutan Ketujuh, kredibilitas. Pustakawan harus mempunyai sifat jujur dan dapat dipercaya.

Delapan, keamanan. Perpustakaan bebas dari bahaya, risiko atau keraguan-raguan, dan aman dari pencurian. Keamanan ini meliputi keamanan diri pemustaka, barang bawaan, bencana, dan lain-lain. Perpustakaan dapat menugaskan petugas keamanan untuk pengawasan orang dan barang-barang. Selain itu, perpustakaan menyediakan tempat khusus untuk menyimpan tas dan barang berharga milik pengunjung.

Sembilan, kemampuan memahami pemustaka. Perpustakaan dan pustakawan berupaya memahami kebutuhan koleksi yang dibutuhkan oleh pemustaka, memberikan perhatian secara individu, dan mengenal lebih mendalam kebutuhan pemustaka secara umum. Sepuluh, bukti fisik. Bukti fisik atau tangibles, meliputi gedung, sarana prasarana, peralatan, personel, dan alat komunikasi.

Dipertegas pendapat Tjiptono (2012: 182), bahwa untuk mewujudkan layanan yang prima, perlu memperhatikan beberapa faktor, yaitu kualitas layanan, mengelola ekspektasi pelanggan, mengelola bukti kualitas layanan, mendidik konsumen tentang layanan, menumbuhkembangkan budaya kualitas, menciptakan automating quality, menindaklanjuti layanan, dan mengembangkan sistem informasi. Selain itu, ada lima dimensi pokok layanan, antara lain: reliabilitas, daya tanggap, jaminan, empati, dan bukti fisik.

\section{Menciptakan Layanan Perpustakaan yang Prima dan Unggul}

Agar perpustakaan menjadi jantungnya perguruan tinggi dan dapat menggerakkan atmosfer pembelajaran di perguruan tinggi, maka perpustakaan dapat menyediakan koleksi, jenis layanan, sarana prasarana, dan ruang perpustakaan yang dapat mendukung visi misi perguruan tinggi induknya. Perpustakaan dapat 
melakukan terobosan dalam memperdayakan perpustakaan, baik dari segi koleksi, jenis layanan, jam buka perpustakaan, sarana prasarana, kualitas sumber daya manusia, kebersihan lingkungan, penataan ruang, dan desain interior perpustakaan untuk menciptakan layanan yang prima.

Tujuan dari layanan prima adalah pertama, fokus pada pemustaka. Perpustakaan bergantung pada pemustaka sehingga pustakawan harus bisa memahami kebutuhan masa kini dan mendatang pemustaka, sertaberusaha memenuhi persyaratan dan melebihi harapan pemustaka. Kedua, memberikan layanan perpustakaan yang dapat memberikan kepuasan. Perpustakaan harus mengenal karakter pemustaka dengan baik agar dapat menghadapi dan memberikan layanan sesuai dengan karakter yang berbedabeda tersebut

Layanan perpustakaan yang prima merupakan layanan perpustakaan yang dapat memberikan kepuasan bagi pemustaka dan pengunjung perpustakaan. Untuk mewujudkan layanan yang prima, perpustakaan dapat membuat standar pelayanan prima yang sesuai dengan fungsi perpustakaan dan memperhatikan karakteristik pemustaka yang akan dilayani.

Dalam memberikan layanan kepada pemustaka, pustakawan dapat mempelajari dari jenis karakteristik kepribadian pemustaka. Memberikan layanan kepada pemustaka pendiam dan pemustaka yang banyak bicara tentu akan berbeda cara menghadapinya. Hal ini dipertegas Prastowo (2012: 290), bahwa cara menghadapi Pemustaka yang memiliki karakteristik yang berbeda akan diberlakukan yang berbeda dan disesuaikan dengan Karakteristik Pribadi Pemustaka tersebut.

Berikut ini gambaran tentang cara menghadapi dan melayani pengguna sesuai dengan karakteristik pengguna seperti yang dijelaskan oleh Prastowo (2012: 290). Pertama, pemustaka yang pendiam. (a) Pengguna yang pendiam dan pemalu akan merasa tentram jika dilayani dengan ramah dan penuh perhatian, (b) melontarkan pertanyaan-pertanyaan yang dapat menarik perhatian pada produk-produk yang ditawarkan oleh perpustakaan perguruan tinggi.

Kedua, cara menghadapi pengguna yang tidak sabar. (a) Pustakawan berusaha mengenali melalui sikapnya lalu meminta maaf kepada pemustaka atas tertundanya layanan, (b) mengatakan kepadanya bahwa akan dibantu dengan maksimal dan sesegera, (c) secara cepat dan efisien menangani situasi, (d) mengucapkan terima kasih atas kesediaannya menunggu, (e) mengucapkan terima kasih kepada pemustaka atas ketidaknyaman dalam pelayanan.

Ketiga, cara menghadapi pengguna yang banyak bicara. (a) Mengenali pemustaka dengan mengucapkan salam, (b) menawarkan bantuan, (c) memberikan informasi tentang jenis layanan, koleksi, dan cara melakukan penelusuran.

Keempat, cara menghadapi pengguna yang suka berdebat. (a) bersikap tenang, tidak gugup, dan tidak terpancing emosi, (b) membatasi percakapan pada masalah yang sedang dihadapi, (c) kemukakan argumen yang masuk akal, (d) ulangi argumen sebagai pengingat apabila pemustaka tetap bersikeras dengan pendapatnya, (e) cari kelemahan dari argumen pemustaka dan tunjukkan kekeliruannya agar tenang.

Kelima, cara menghadapi pengguna yang banyak permintaan. (a) Ucapkan salam, (b) mendengarkan permintaannya, (c) segera memenuhi permintaan apabila memungkinkan, (d) meminta maaf dan memberikan alternatif lain jika merasa tidak puas dengan layanan yang telah diberikan, (e) meminta bantuan pustakawan lain apabila tidak dapat mengatasi permintaan pemustaka.

\section{Memperkuat Peran Pustakawan}

Pustakawan harus mempersiapkan diri sebelum melaksanakan tugas kepustakawanan. Pustakawan akan berhubungan langsung 
dengan pemustaka yang mempunyai karakter berbeda-beda. Pustakawan dapat memberikan layanan yang optimal untuk mewujudkan layanan prima dan unggul. Masalah pribadi yang timbul dari masalah keluarga sebaiknya tidak dibawa ke perpustakaan sehingga tidak mengganggu layanan. Pustakawan yang berinteraksi langsung dengan pemustaka harus memiliki kemampuan, antara lain: berorientasi kepada pemustaka, dapat berkomunikasi dengan baik, berpenampilan yang rapi, bersikap sopan, dan mengimplementasikan teknologi informasi dalam melakukan tugas kepustakawan

Pustakawan dapat meningkatkan kompetensi diri dalam rangka mewujudkan layanan perpustakaan yang prima dan unggul melalui pendidikan, pelatihan, worskhop, lokakarya dan seminar. Pustakawan harus siap menghadapi perubahan sebagai upaya dalam peningkatan layanan perpusakaan yang lebih baik. Menurut Tjitropranoto (dalam Purwono, 2013: 55), untuk menghadapi tantangan masa depan, pustakawan dapat meningkatkan kualitas pustakawan, yaitu (1) mempunyai kemampuan untuk berorientasi kepada pemustaka, (2) memiliki kemampuan berkomunikasi dengan orang lain, (3) memiliki kemampuan teknis di bidang perpustakaan, (4) dapat berbahasa asing, terutama bahasa Inggris, (5) mampu mengembangkan teknik dan prosedur kerja di bidang perpustakaan, (6) mampu memanfaatkan perkembangan ilmu pengetahuan dan teknologi untuk keperluan pengembangan perpustakaan

Sedangkan Rohmadi, dalam Pengarahan Intergasi Perpustakaan UNS Tanggal 1 Februari 2015 di UPT Perpustakaan Universitas Sebelas Maret, menegaskan bahwa dalam mewujudkan layanan prima dan unggul, maka pustakawan dalam melakukan layanan perpustakaan harus memperhatikan beberapa hal, yaitu kemampuan, penampilan, dan bersikap sopan kepada pemustaka.

Dipertegas oleh Shakuntala (2011: 1) bahwa kualitas layanan tergantung kepada petugas yang memberikan layanan. untuk memperoleh layanan yang baik diperlukan Standar Operasional Prosedur dalammelakukan layanan. Petugas yang akan memberikan layanan harus mengerti dan memahami dasar-dasar pelayanan, antara lain: (1) pakaian dan penampilan rapi bersih, (2) percaya diri, bersikap ramah, (3) akrab dan penuh senyum, (4) menyapa dengan lembut dan menyebutkan nama pelanggan, (5) sopan, tenang, sabar, dan mendengarkan setiap pembicaraan, (6) mendengarkan pembicaraan pelanggan dan menerima keluhan, (7) berbicara jelas menggunakan bahasa yang baik dan benar, (8) antusias dalam melayani dan tunjukkan kemampuan, (9) jangan memotong dan menyela pembicaraan,(10) mampu menyakinkan pelanggan, dan (11) apabila tidak bisa mengatasi permasalahan, maka minta bantuan.

Dari pendapat di atas, penulis memberikan kesimpulan bahwa untuk memperkuat peran pustakawan dalam mendukung terwujudnya layanan prima dan unggul, maka pustakawan harus memperhatikan beberapa hal. Pertama, meningkatkan kompetensi kepustakawanan. Kompetensi pustakawan dan staf perpustakaan harus ditingkatkan sehingga dalam memberikan layanan kepada pemustaka akan menghasilkan layanan yang optimal. Pustakawan harus memahami koleksi yang dimiliki, jenis layanan, cara akses koleksi, elektronik jurnal dan buku yang dilanggan, alamat website, digital library, cara melakukan penelusuran informasi, hal-hal lain yang berkaitan dengan program perpustakaan dan lain sebagainya. Semua pustakawan, staf perpustakaan dan sampai pegawai level bawah harus mengetahui informasi tentang perpustakaan.

Kedua, penampilan. Dalam memberikan layanan perpustakaan, kerapian pakaian pustakawan harus diperhatikan. Dengan demikian, pemustaka akan merasa dihargai dan dihormati. Pakaian yang dikenakan tidak harus yang baru, tetapi pakaian yang pantas, tidak kotor dan sobek. Selain pakaian, rambut, 
sepatu, dan sebagainya juga dapat diperhatikan agar penampilan pustakawan dapat menghargai pemustaka. Seperti filosofi dari orang-orang terdahulu, yang bunyinya Ajining Rogo Soko Busono. Artinya, seseorang akan dihargai dan dihormati dari pakaian yang dikenakan. Jadi, cara berpakaian pustakawan secara tidak langsung akan berdampak pada kualitas layanan di perpustakaan.

Ketiga, percaya diri, penuh senyum, bersikap ramah, dan bersahabat. Pustakawan harus menguasai informasi yang dimiliki perpustakaan. Setiap pertanyaan dari pemustaka dapat dijawab dengan penuh keyakinan dan percaya diri. Pustakawan bersikap bersahabat dengan pemustaka. Sikap pustakawan harus sopan, santun, ramah, respek dan atensi. Kesopanan ini dapat ditunjukkan saat melakukan layanan perpustakaan, menerima telepon, dan menerima tamu, baik dari internal maupun eksternal instansi. Pemustaka yang datang ke perpustakaan disambut dengan $5 \mathrm{~S}$, yaitu senyum, salam, sapa, sopan dan santun. Seperti pada layanan bank, maka setiap pelanggan yang datang akan disambut dengan ramah, pintu masuk dibukakan oleh satpam, kemudian disambut dengan senyuman, memberikan salam dan ditanya apa yang bisa dibantu.

Keempat,mendengarkan setiappembicaraan dan menerima keluhan dengan baik. Pustakawan harus mendengarkan pembicaraan dan berusaha menerima keluhan dari pemustaka. Dengan demikian, pemustaka akan merasa dihargai dan hormati oleh perpustakaan.

Kelima, berbicara dengan bahasa yang benar dan jelas. Bahasa yang digunakan dalam melakukan layanan perpustakaan menggunakan bahasa Indonesia. Suara yang digunakan harus jelas, mudah dipahami, dan tidak menggunakan istilah yang tidak dimengerti oleh pemustaka.

Keenam, antusias dalam memberikan layanan dan tunjukkan kemampuan. Pustakawan papat menunjukkan layanan yang prima dengan memahami keinginan dan kebutuhan pemustaka. Dalam memberikan layanan, pustakawan harus memiliki kemampuan dan pengetahuan tentang sumber daya perpustakaan yang dimiliki, seperti koleksi, layanan, sarana prasarana, sumber daya manusia, cara akses informasi perpustakaan, langganan elektronik jurnal, buku, dan sebagainya, yang ada kaitannya dengan perpustakaan.

Ketujuh, apabila tidak bisa mengatasi permasalahan yang ada, dapat bekerja sama dengan pustakawan lain. Pada waktu memberikan layanan dan menemukan permasalahan yang tidak dapat diselesaikan sendiri, maka pustakawan dapat bekerja sama dengan pustakawan lain yang sanggup dan mengerti akan permasalahan tersebut atau permasalahan di luar wewenang pustakawan yang bersangkutan.

\section{PENUTUP}

Dalam rangka mewujudkan layanan prima dan unggul, perpustakaan perguruan tinggi dapat membuat standar pelayanan prima yang sesuai dengan tugas dan fungsi perpustakaan tersebut. Dengan standar pelayanan prima, kinerja layanan dapat terukur dan terlihat.

Kualitas layanan perpustakaan tergantung darikemampuan pustakawan dalammemberikan layanan kepada pemustaka. Pustakawan berada di garis depan dan berhubungan langsung dengan pemustaka. Pustakawan harus memiliki kemampuan, antara lain: berorientasi kepada pemustaka, dapat berkomunikasi dengan baik, berpenampilan rapi, bersikap sopan, dan mengimplementasikan teknologi informasi dalam melakukan tugas kepustakawan. Pengetahuan pustakawan tentang dasardasar pelayanan dapat ditingkatkan melalui pendidikan, pelatihan, lokakarya, workshop, dan seminar.Ada pun strategi pustakawan dalam memperkuat perannya dalam mewujudkan layanan perpustakaan perguruan tinggi yang unggul dan prima, antara lain: (1) 
meningkatkan kompetensi kepustakawanan, dengan bahasa yang benar dan jelas, (6) (2) menjaga penampilan, (3) percaya diri, antusias dalam memberikan layanan dan penuh senyum, bersikap ramah, dan bersahabat, tunjukan kemampuan, serta (7) apabila tidak (4) mendengarkan setiap pembicaraan dan bisa mengatasi permasalahan yang ada dapat menerima keluhan dengan baik, (5) berbicara bekerja sama dengan pustakawan lain.

\section{DAFTAR PUSTAKA}

Ismawan, Laurentius Denni. 2014. "Dampak Teknologi Informasi di Perpustakaan terhadap Perilaku Pemustaka. Diakses tanggal 28 Januari 2016 melalui http:// perpustakaan.kaltimprov.go.id/berita-598--dampak-teknologi-informasi-diperpustakaan terhadap-perilaku-pemustaka.html

Prastowo, Andi. 2012. Manajemen Perpustakaan Sekolah Profesional. Yogyakarta: Diva Press.

Purwono. 2013. Profesi Pustakawan Menghadapi Tantangan Perubahan. Yogyakarta: Graha Ilmu.

Rohmadi, Muhammad. 2015. Rapat Koordinasi dalam Rangka Integrasi Perpustakaan UNS pada tanggal 1 Februari 2015 di Ruang Sidang UPT Perpustakaan UNS.

Shakuntala, Margaretha. 2011. "Pentingnya Standar Operasional Prosedur bagi Petugas Pelayanan Pelanggan". Diakses tanggal 2 Februari 2015 melalui http://www.scribd.com/doc/98495058/Pentingnya-Standar-Operasional-Prosedur-Bagi Petugas-Pelayanan-Pelanggan\#scribd.

Tjiptono, Fandy. 2012. Service Management: Mewujudkan Layanan Prima. Yogyakarta: Andi Undang-Undang Nomor 43 Tahun 2007 tentang Perpustakaan 